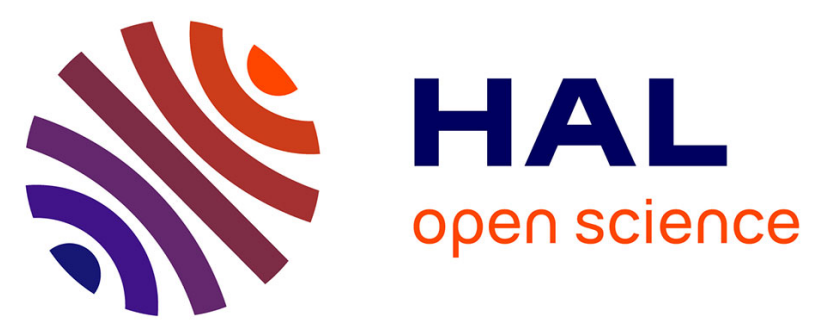

\title{
Droplet Digital PCR combined with minisequencing, a new approach to analyze fetal DNA from maternal blood: application to the non-invasive prenatal diagnosis of achondroplasia.
}

Lucie Orhant, Olivia Anselem, Mélanie Fradin, Pierre Hadrien Becker, Caroline Beugnet, Nathalie Deburgrave, Gilles Tafuri, Franck Letourneur, François Goffinet, Laïla Allach El Khattabi, et al.

\section{- To cite this version:}

Lucie Orhant, Olivia Anselem, Mélanie Fradin, Pierre Hadrien Becker, Caroline Beugnet, et al.. Droplet Digital PCR combined with minisequencing, a new approach to analyze fetal DNA from maternal blood: application to the non-invasive prenatal diagnosis of achondroplasia.. Prenatal Diagnosis, 2016, 36 (5), pp.397-406. 10.1002/pd.4790 . hal-01272602

HAL Id: hal-01272602

https://hal-univ-rennes1.archives-ouvertes.fr/hal-01272602

Submitted on 11 Feb 2016

HAL is a multi-disciplinary open access archive for the deposit and dissemination of scientific research documents, whether they are published or not. The documents may come from teaching and research institutions in France or abroad, or from public or private research centers.
L'archive ouverte pluridisciplinaire HAL, est destinée au dépôt et à la diffusion de documents scientifiques de niveau recherche, publiés ou non, émanant des établissements d'enseignement et de recherche français ou étrangers, des laboratoires publics ou privés. 


\section{$\underline{\text { Title }}$}

Droplet Digital PCR combined with minisequencing, a new approach to analyze fetal DNA from maternal blood: application to the non-invasive prenatal diagnosis of achondroplasia

\section{Running Head}

Non-invasive prenatal diagnosis of achondroplasia by ddPCR and minisequencing

\section{$\underline{\text { Authors and affiliations }}$}

Lucie Orhānt (1), Olivia Anselem, MD (2), Mélanie Fradin MD (3), Pierre Hadrien Becker

(1), Caroline Beugnet (1), Nathalie Deburgrave (1), Gilles Tafuri (1), Franck Letourneur PhD (4), François Goffinet, MD, PhD (2), Laïla Allach El Khattabi, PharmD (5) France Leturcq, PharmD (1), Thierry Bienvenu, PharmD, PhD (1,4), Vassilis Tsatsaris, MD, PhD (2), Juliette Nectoux, PharmD, PhD $(1,4)$

(1) Service de Biochimie et Génétique Moléculaire, HUPC Hôpital Cochin, Paris, France

(2) Maternité Cochin-Port Royal, HUPC Hôpital Cochin, Paris, France

(3) Service de Génétique Médicale, CHU de Rennes, Rennes, France

(4) INSERM, U1016, Institut Cochin, CNRS UMR8104, Université Paris Descartes, Paris, France

(5) Laboratoire de Cytogénétique, HUPC Hôpital Cochin, Paris, France 


\section{Correspondance}

Dr Juliette Nectoux, Service de Biochimie et Génétique Moléculaire, HUPC Hôpital Cochin, 27 rue du faubourg St Jacques, 75014 Paris, France. Tel : 003315841 16 22, Fax : 00331

5841 15 80, E-mail : juliette.nectoux@aphp.fr

\section{Funding sources}

This work received financial support from the Agence de la Biomédecine (Project R13188KK) and the association Vaincre la mucoviscidose (Project RC2013500852). No involvement of the funder in the study design, data collection, data analysis, manuscript preparation and/or publication decisions.

\section{The authors declare no conflict of interest}

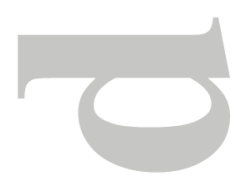

\section{$\underline{\text { Bulleted statements }}$}

We developed an original strategy for the NIPD of achondroplasia from maternal blood, combining ddPCR with minisequencing. This diagnosis provides a rapid and definitive diagnosis for parents that are in a painful context of a sudden discovery of abnormal prenatalultrasound findings in the third trimester of pregnancy, as well as an early diagnosis for parents aware of the risk because of familial history, allowing an appropriate clinical management of pregnancy. 


\section{$\underline{\text { Abstract }}$}

Background. Achondroplasia is generally detected by abnormal prenatal ultrasound-findings in the third trimester of pregnancy, and then confirmed by molecular genetic testing of fetal genomic DNA obtained by aspiration of amniotic fluid. This invasive procedure presents a small but significant risk for both the fetus and mother. Therefore, non-invasive procedures using cell-free-fetal DNA in maternal plasma have been developed for the detection of the fetal achondroplasia mutations. Methods. To determine whether the fetus carries the de novo nonsense genetic mutation at nucleotide 1138 in FGFR3 gene involved in $>99 \%$ of achondroplasia cases, we developed two independent methods: digital-droplet PCR combined with minisequencing, which are very sensitive methods allowing detection of rare alleles. Results. We collected 26 plasmatic samples from women carrying fetus at risk of achondroplasia, and diagnosed to date a total of five affected fetuses in maternal blood. The sensitivity and specificity of our test are respectively 100\% [95\% confidence interval, 56.6 to $100 \%$ ] and $100 \%$ [95\% confidence interval, 84.5 to 100\%]. Conclusions. This novel, original strategy for non-invasive prenatal diagnosis of achondroplasia is suitable for implementation in routine clinical testing and allows considering extending the applications of these technologies in non-invasive prenatal diagnosis of many other monogenic diseases. 


\section{Introduction}

Achondroplasia (MIM: 100800) is one of the chondrodysplasia which can be diagnosed prenatally. This autosomal dominant genetic disease, also known as chondrodystrophic dwarfism $^{1,2}$, is the most common nonlethal form of skeletal dysplasia with an estimated incidence rate of one in 20,000 live births.

Achondroplasia is caused by mutations of the transmembrane receptor fibroblast growth factor receptor 3 gene FGFR3 (MIM: 134934), which encodes an important regulator of linear bone growth ${ }^{3}$. In normal development FGFR3 has a negative regulatory effect on bone growth. In achondroplasia, the mutated form of the receptor is constitutively active and this leads to severely shortened bones. Approximately $98 \%$ of patients with achondroplasia have a de novo nonsense genetic mutation in FGFR3 gene with a guanine to adenine transition at nucleotide 1138 resulting in a glycine to arginine substitution at position 380 (c.1138G>A, p.Gly380Arg), while around $1 \%$ present a guanine to cytosine transversion at the same position (c.1138G>C, p.Gly380Arg mutation) ${ }^{4}$.

Achondroplasia is generally detected either on family history of achondroplasia or during routine ultrasound in the third trimester of pregnancy, on the basis of characteristic skeletal features such as shortened long bones with bowed femora, macrocephaly, frontal bossing and trident hand. Molecular prenatal genetic testing offers an early, rapid and reliable diagnosis, through the testing of fetal genomic DNA obtained by amniocentesis. These invasive procedures present a small but significant risk for both the fetus and mother. Therefore, noninvasive procedures using cell-free fetal DNA (cffDNA) in maternal plasma have been developed for the detection of the fetal achondroplasia mutation.

In 1997, inspired by the presence of tumor DNA in the plasma and serum of patients suffering from cancer ${ }^{5}$, Lo et al. showed the presence of cell-free fetal DNA in the plasma 
and serum of pregnant women ${ }^{6}$. Therefore, the discovery of cffDNA has opened the field for many applications of non-invasive prenatal diagnosis, the vast majority being developed from maternal plasma. The DNA extracted from maternal plasma, also known as cell-free DNA (cfDNA) or circulating DNA, is formed by a mixture of cf DNA of maternal origin $(\sim 90 \%)$ and cfDNA of fetal origin $(\sim 10 \%)^{7}$. The development in 2011 of a droplet digital PCR system (ddPCR) allowed to optimize sensitivity, specificity and accuracy for the detection and analysis of nucleic acids of low abundance, such as cfDNA. Its principle is based on the partitioning of biological sample in tens of thousands of microdroplets of 1 nanoliter, wherein the plasmatic DNA fragments are distributed. When compared with the traditional technique of real time quantitative PCR, the partitioning step of ddPCR allows to reduce the effects of competition due to the presence in plasma of a large excess of maternal DNA, and thus increases the specificity and sensitivity of the detection of cfDNA of fetal origin.

Combining this new, original approach of ddPCR with minisequencing, we developed a new strategy for the non-invasive prenatal diagnosis of achondroplasia. Since 2013, close to 190 plasmatic samples were collected from women at risk of transmitting monogenic disorders, such as Duchenne muscular dystrophy, hemophilia, cystic fibrosis, neurofibromatosis type 1 or achondroplasia. Among those, 26 samples were collected from women carrying fetus at risk of achondroplasia, on the basis of abnormal prenatal ultrasound findings in the third trimester of pregnancy. This allowed us to diagnose to date a total of five cases of achondroplasia in maternal blood. 


\section{Methods}

\section{Participants}

Two achondroplastic patients previously diagnosed with FGFR3 mutations by standard methods (sequence of the DNA isolated from peripheral blood leucocytes) with c.1138G $>A$ and c. $1138 \mathrm{G}>\mathrm{C}$ mutation respectively, were used to create artificial mixtures of DNA with very low concentrations and variable proportions of mutant allele to test sensitivity and specificity of our assays. A healthy pregnant woman with 22 weeks of pregnancy of a fetus with characteristic skeletal features of achondroplasia and whose husband carried the c. $1138 \mathrm{G}>\mathrm{A}$ mutation was studied as a positive control to determine whether studying cfDNA could be used for the diagnosis of the fetal c.1138G>A mutation. Additionally, a total of 25 pregnant women with an echographic suspicion of fetal chondrodysplasia were recruited. Two additional healthy subjects, negative for FGFR3 mutation, were used as negative controls. Written informed consent was obtained prior to venepuncture and the study was ethically approved by the Comité Consultatif sur le Traitement de l'Information en matière de Recherche dans le domaine de la Santé (CCTIRS - ref 13.386) and the Comité de Protection des Personnes (CPP - ref 2014-janvier-13465). In all cases, confirmation of prenatal testing result was done by conventional procedures, blindly to the results of non-invasive testing.

\section{Sample collection}

For each pregnant patient, two tubes of blood were collected by venipuncture in BCT CellFree DNA ${ }^{\mathrm{TM}}$ Blood Collection Tube (Streck, Omaha, NE). Plasma samples were separated after double centrifugation within 4 days of collection, one at $1600 \mathrm{~g}$ for 10 minutes and the second at $16000 \mathrm{~g}$ for 10 minutes. The buffy coats were retained. The whole was frozen at -80

${ }^{\circ} \mathrm{C}$ in a sterile tube. In all cases, a tissue of fetal origin was taken invasively by puncture of 
the amniotic fluid ( $\mathrm{n}=26$ samples). For these cases, the blood collection was performed before invasive sampling.

\section{DNA extraction}

cfDNA was extracted from three mL of plasma using the QIAamp Circulating Nucleic Acid (Qiagen, Valencia, CA) according to the protocol recommended by the manufacturer in a laboratory dedicated exclusively for this purpose. The extracted cfDNA was eluted in $100 \mu \mathrm{L}$ of elution buffer, and stored at $-20^{\circ} \mathrm{C}$ until use. The maternal nuclear DNA and the fetal nuclear DNA were extracted respectively from buffy coats or amniotic fluid by the automatic extractor Maxwell (Promega, Madison, USA), according to the recommendations provided by the manufacturer.

\section{Sanger sequencing}

For the conventional prenatal diagnosis of achondroplasia from fetal nuclear DNA extracted from amniotic fluid, a PCR is performed on thermal cycler Applied Biosystem 9700, generating a product of $559 \mathrm{bp}$, containing the 1138 position of the FGFR3 gene exon 9 . Primer sequences and cycling conditions are described in Table 1. PCR reactions were performed in a total volume of $50 \mu \mathrm{L}$ with a reaction mixture containing $1 \mu \mathrm{L}$ of eluted DNA, $1 \mu \mathrm{L}$ each primer $(10 \mu \mathrm{M}), 3 \mu \mathrm{L} \mathrm{MgCl} 2(25 \mathrm{mM})$ and $5 \mu \mathrm{L} 10 \mathrm{X}$ buffer. After a purification step, sequencing reactions were performed in a total volume of $20 \mu \mathrm{L}$ with a reaction mixture containing $3 \mu \mathrm{L}$ of purified PCR product, $1 \mu \mathrm{L}$ of either forward or reverse primer $(10 \mu \mathrm{M}), 2$ $\mu \mathrm{L}$ of $5 \mathrm{X}$ BigDye buffer (applied Biosystems) and $4 \mu \mathrm{L}$ of enzyme Big Dye V1.1. The same primers were used for sequencing and cycling conditions are described in Table 1.

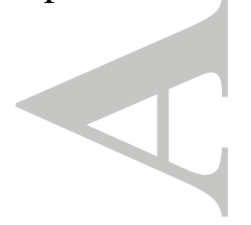




\section{Digital Droplet PCR}

To determine whether the fetus carries a de novo nonsense genetic mutation at nucleotide 1138 in FGFR3 gene, ddPCR method based on the amplification of the two possible mutant alleles -A-allele or C-allele - and the wild-type G-allele was developed. Primer sequences are described in Table 1. The presence or absence of amplification for the mutant allele signs therefore the presence or absence of mutant FGFR3 sequences of fetal origin in the maternal plasma, which indicates a genotype of the fetus FGFR3 mutant or wild-type (WT) respectively. Moreover, the amplification of the promoter region of RASSF1A gene differentially methylated between the mother and her fetus also ensures the presence of DNA of fetal origin ${ }^{8}$ ( (Table 1).

Droplet digital PCR was performed using the QX100 ${ }^{\mathrm{TM}}$ Droplet Digital ${ }^{\mathrm{TM}}$ PCR System from BioRad (Hercules, CA) according to the manufacturer's instructions. Briefly, three duplex PCR are carried out in two replicates: mutant FGFR3 A-allele and WT FGFR3 G-allele are amplified together as well as mutant FGFR3 C-allele / WT FGFR3 G-allele and RASSF1A / ACTIN B. In each well, $9 \mu \mathrm{L}$ of the eluted cfDNA solution were mixed with $10 \mu \mathrm{L}$ of ddPCR master mix (BioRad), and $1 \mu \mathrm{L}$ of each duplex PCR primers/probes. Droplets were generated using the Droplet Generator (DG) with $70 \mu \mathrm{L}$ DG Oil per well with a DG8 cartridge and cartridge holder, $21 \mu \mathrm{L}$ PCR reaction mix, and DG8 gasket. Droplets were dispensed into the 96-well PCR plate by aspirating $40 \mu \mathrm{L}$ from the DG8 cartridge into each well. The PCR plate was then heat-sealed with a foil seal and the sealed plate was placed in the PCR thermocycler (thermal conditions in table 1). After the reaction, the droplets were read using the Droplet Reader, and QuantaSoft software converted the data into concentrations using Poisson distribution statistical analysis. Detecting a fluorescence indicates that specific amplification has occurred, and thus that the genomic target was initially present in the biological sample. 
The decision algorithm is presented in Figure 1. Briefly, a concomitant amplification of either FGFR3 mutant A-allele or mutant C-allele with the FGFR3 WT G-allele indicates an achondroplastic fetus. After PCR amplification of cfDNA from healthy pregnant women, result was considered positive when $>10,000$ droplets were generated in each well, and when 2 replicates showed more than 5 positive droplets for the mutant allele each. The absence of amplification of FGFR3 mutant A-allele and mutant $\mathrm{C}$-allele, together with the positive amplification of the FGFR3 WT G-allele and the demonstration of the presence of cffDNA (through RASSF1A assay) indicated a fetus free of the hotspot mutation of nucleotide 1138 of FGFR3 gene. The fetal fraction was estimated through RASSF1A/ B-ACTIN assay as previously described $^{8}$. Briefly, co-amplification of RASSF $1 A$ and B-ACTIN was performed, before and after BstUI digestion (New England Biolabs, Beverly, MA, USA). In absence of droplets positive for $B$-ACTIN after digestion, fetal fraction was calculated as follow: $\left[(\mathrm{RASSF} 1 \mathrm{~A})_{\text {post-digestion }} /(\mathrm{RASSF} 1 \mathrm{~A})_{\text {pre-digestion }}\right] \%$. In order to prevent false negative results due to low fetal fraction, in case of fetal fraction $<4 \%$, a new analysis is recommended on a second sample two weeks later.

\section{Minisequencing}

PCR amplification and minisequencing reaction primers were designed using the Primer3 software (http://frodo.wi.mit.edu/primer3/). PCR amplification was performed using the LightCycler 480 HRM Master (Roche Diagnostics, Penzberg, Germany). Minisequencing was performed using the SNaPshot ${ }^{\mathrm{TM}}$ kit (Applied Biosystems, Foster City, CA). All reactions were performed according to manufacturer's protocols. PCR reactions were performed in a total volume of $20 \mu \mathrm{L}$ with a reaction mixture containing $5 \mu \mathrm{L}$ of eluted DNA at a concentration of $2 \mathrm{ng} / \mu \mathrm{L}, 1 \mu \mathrm{L}$ each primer $(5 \mu \mathrm{M}), 2.4 \mu \mathrm{L} \mathrm{MgCl} 2(25 \mathrm{mM})$ and $10 \mu \mathrm{L}$ 2X Master Mix. Primers and cycling conditions for FGFR3 amplification and minisequencing assay are described in table 1. After the Exo/sap enzymatic purification step, sequencing 
reactions were performed in a total volume of $10 \mu \mathrm{L}$ with a reaction mixture containing $3 \mu \mathrm{L}$ of purified PCR product, $1 \mu \mathrm{L}$ each primer $(2 \mu \mathrm{M})$ and $5 \mu \mathrm{L}$ of SnapShot Multiplex Ready Reaction Mix. PCR products were sequenced on 3130xl genetic analyzer (Applied Biosystems), analyzed with GeneMapper software (Applied Biosystems) and compared to minisequencing results in two achondroplastic subjects with FGFR3 c.1138G>A and c. $1138 \mathrm{G}>\mathrm{C}$ mutation respectively and in two healthy controls.

\section{$\underline{\text { Results }}$}

Genotyping the FGFR3 c.1138G>A and c.1138G>C mutations by ddPCR and minisequencing in DNA isolated from peripheral blood leucocytes

To test the ability of our ddPCR and minisequencing methods to detect of the FGFR3 mutations in a small quantity of $F G F R 3$ mutant DNA, we used samples mimicking cfDNA from pregnant women. Peripheral bloods were obtained from a non-pregnant female carrier of the mutant A-allele, a non-pregnant female carrier of the mutant $\mathrm{C}$-allele and two nonpregnant females blood donor without FGFR3 mutation. Given that cfDNA is characterized by a low concentration of fetal DNA and a mix of maternal and fetal DNA, we created artificial mixtures of DNA from FGFR3 WT lymphocytes with DNA from FGFR3 mutant lymphocytes at very low concentrations and variable proportions of mutation. We tested our ddPCR multiplex assays with artificial mixtures of $0.5 \mathrm{ng} / \mu \mathrm{L}$ DNA (containing $50 \%, 25 \%$, $12 \%, 6 \%, 3 \%, 1.5 \%, 0.8 \%, 0.4 \%$ or $0 \%$ of mutant allele). As shown in Figure 2, both ddPCR FGFR3 mutant $\mathrm{A}$ and mutant $\mathrm{C}$ allele specific assays are able to discriminate as low as $0.8 \%$ and $0.4 \%$ of mutant DNA, respectively. Similarly, we tested our minisequencing assays with artificial mixtures of $0.5 \mathrm{ng} / \mu \mathrm{L}$ DNA (containing $50 \%, 25 \%, 12 \%, 6 \%, 3 \%, 1.5 \%, 0.8 \%$ or $0 \%$ of mutant allele). As shown in Figure 3, both minisequencing FGFR3 mutant A and 
mutant $\mathrm{C}$ allele specific assays are able to discriminate down to 1.5 and $3 \%$ of mutant DNA, respectively. Altogether, these results show that these methods are sensitive and specific enough to detect small amounts of FGFR3 mutation in a background of WT DNA in large excess.

Genotyping the FGFR3 c.1138G>A mutation by ddPCR and minisequencing in cfDNA from maternal blood

We also studied a healthy pregnant woman with 22 weeks of pregnancy of a fetus with characteristic skeletal features of achondroplasia and whose husband carried the c.1138G>A mutation to determine whether ddPCR and minisequencing assays were able to discriminate the fetal FGFR3 c.1138G>A mutation from maternal plasma. As shown in figure 4, both assays are able to detect the $F G F R 3$ mutant A allele in cfDNA from maternal blood, thus confirming the affected status of the fetus (Figure 4). This case is considered as our positive control (Table 2, case 22).

Non-invasive prenatal diagnosis of achondroplasia by ddPCR and minisequencing in cfDNA from maternal blood

We collected 25 additional plasmas from women carrying fetus at risk of achondroplasia, on the basis of abnormal prenatal ultrasound findings in the third trimester of pregnancy. All samples were tested with both ddPCR and minisequencing assays. As shown in table 2, ddPCR and minisequencing analysis classified correctly the healthy and the affected fetuses, as compared to the results of Sanger sequencing from fetal DNA obtained through conventional prenatal screening. In addition to the case based on family history, which is considered as our positive control, four other pregnant women carrying FGFR3 fetuses were classified as mutant, being clearly differentiated from negative controls. Altogether, the 
sensitivity and specificity of our test are $100 \%$ respectively [95\% confidence interval, 56.6 to $100 \%$ ] and $100 \%$ [95\% confidence interval, 84.5 to $100 \%$ ].

\section{Discussion}

The study of cfDNA is becoming a crucial tool for diagnosis and management in various clinical disorders. Indeed, increased levels of cfDNA have been reported in a number of clinicopathological conditions such as cancer, stroke, trauma, myocardial infarction, autoimmune disorders and pre-eclampsia ${ }^{8-15}$. Additionally, cfDNA from fetal origin can also be detected in the plasma of the mother as early as from the 5 th week of gestation ${ }^{16}$ opening the field for many applications of non-invasive prenatal testing (NIPT) such as fetal gender determination ${ }^{16,17}$ or RHD genotyping ${ }^{18}$, chromosomal aneuploidies ${ }^{19-23}$, and an increasing number of single gene disorders ${ }^{24-30}$.

In this work, we developed a novel and original strategy based on droplet digital PCR combined with minisequencing, allowing the non-invasive prenatal diagnosis of achondroplasia. 26 samples were collected from women carrying fetus at risk of achondroplasia, on the basis of family history or abnormal prenatal ultrasound findings in the third trimester of pregnancy, such as rhizomelic shortening of the long bones below the first percentile associated with macrocephaly. This allowed us to diagnose to date a total of five cases of achondroplasia in maternal blood. Four of these were detected by abnormal prenatal ultrasound findings in the third trimester of pregnancy and were done in parallel to conventional prenatal diagnosis, offering a rapid and definitive diagnosis. The fifth was performed at the beginning of the second trimester of pregnancy because of familial history, the father being achondroplastic. This diagnosis did not change the management of pregnancy; however, it allowed an early diagnosis and an appropriate clinical management of 
the newborn. This diagnosis has an important psychological impact since parents can then prepare themselves before the baby is born.

Digital PCR has already been proposed as an alternative technique to other quantitative techniques for NIPT of aneuploidies ${ }^{31-33}$ as well as monogenic disorders ${ }^{26-29}$. Several groups have reported on the diagnosis of achondroplastic fetuses using different analytical techniques such as MALDI-TOF, restriction analysis, QF-PCR, quantitative real time PCR and more recently NGS ${ }^{30,34-39}$. The early PCR-based methods appear to be suitable in diseases for which there is a single hotspot mutation. But because of the inherent properties of cffDNA which is characterized by very low absolute and relative concentrations, such methods may not be sufficiently sensitive for the delivery of accurate results in all cases. Droplet digital PCR, which is based on the partitioning of biological samples, allows to optimize the sensitivity, specificity and accuracy for the detection and analysis of nucleic acids of low abundance, such as cffDNA. When compared with the traditional technique of real time quantitative PCR, the partitioning step of ddPCR reduces the effects of competition due to the presence in plasma of a large excess of maternal DNA, and thus increases the specificity and sensitivity of the detection of cfDNA of fetal origin. Likewise, minisequencing assays have demonstrated a poorer sensitivity as compared to digital PCR, probably because of the effects of competition above mentioned. In order to avoid false negative results with samples containing a low cfDNA fraction, a second sample will be requested two weeks later in case of discordant results between ddPCR and minisequencing assays. Because of the low prevalence of this disorder and the subsequent rare recruitment of patients at our national level, and given that a single nucleotide accounts for approximately 99\% of cases, the implementation of achondroplasia diagnosis in our routine clinical testing by NGS approach appears to be costly and time-consuming.Our combined approach by ddPCR and minisequencing is found to be cost-effective and judicious. 
One limit to the digital PCR approach is that a cfDNA molecule can be counted only if it contains the binding sites for both of the digital PCR primers. Owing to the random fragmentation of cfDNA, only very short cfDNA molecules, are analyzed by a given digital PCR assay. Because of this constraint, the choice of primers and probes is crucial: these must target small sequences. Hence, the amplicons used in the present study did not exceed $90 \mathrm{bp}$ in length. Furthermore, a non-negligible risk of false-negative sample could be a fetal fraction being too low to be detected, even by ddPCR and minisequencing assays. In order to prevent this, we used the amplification of a differentially methylated sequence within the RASSF1A gene's promoter, a universal marker useful for the detection of false-negative results caused by low fetal DNA concentrations in maternal plasma ${ }^{8}$. In order to prevent false negative results due to low fetal fraction, a second sample 2 weeks later is recommended in case of fetal fraction $<4 \%$. Finally, as national French guidelines promote the use of two independent techniques in the context of prenatal diagnosis (www.anpgm.fr), we chose to develop minisequencing assays specific for the target mutations, and these assays appeared to be as effective as ddPCR.

In conclusion, in this work we have developed a novel, original and cost-effective strategy based on droplet digital PCR combined with minisequencing, allowing the non-invasive prenatal diagnosis of achondroplasia from pregnant woman plasma. Although this cohort is of moderate size, it is important to note that no false positive or false negative were observed (sensitivity $100 \%$ [95\% confidence interval, 56.6 to $100 \%$ ] and specificity $100 \%$ [95\% confidence interval, 84.5 to $100 \%]$ ). Promising properties of ddPCR and minisequencing, in terms of accuracy, sensitivity and specificity observed for achondroplasia detection allow us to consider extending the applications of these technologies in non-invasive prenatal diagnosis of many other monogenic diseases. 


\section{Acknowledgments}

This work received financial support from the Agence de la Biomédecine A (Project R13188KK) and the association Vaincre la mucoviscidose (Project RC2013500852). We thank all the centers participating in DANNI project, from geneticists, obstetricians and midwifes to nurses and lab technicians. We thank the families for their participation. We also thank Dr Frederic Fina and the French Digital PCR Working Group for its fruitful discussion.

\section{Bibliography}

1.Horton WA, Hall JG, Hecht JT. Achondroplasia. The Lancet. 2007;370(9582):162-172.

2.Trotter TL, Hall JG, American Academy of Pediatrics Committee on Genetics . Health supervision for children with achondroplasia. Pediatrics. 2005; 116:771-783.

3.Shiang R, Thompson LM, Zhu YZ, et al. Mutations in the transmembrane domain of FGFR3 cause the most common genetic form of dwarfism, achondroplasia. Cell. 1994;78(2):335-342.

4.Bellus GA, McIntosh I, Smith EA, et al. A recurrent mutation in the tyrosine kinase domain of fibroblast growth factor receptor 3 causes hypochondroplasia. Nature Genetics. 1995;10(3):357-359.

5.Chen XQ, Stroun M, Magnenat JL, et al. Microsatellite alterations in plasma DNA of small cell lung cancer patients. Nat Med 1996; 2:1033-35.

6.Lo YM, Corbetta N, Chamberlain PF, et al. Presence of fetal DNA in maternal plasma and serum. Lancet 1997; 350:485-487. 
7.Lun FMF, Chiu RWK, Chan KCA, et al. Microfluidics digital PCR reveals a higher than expected fraction of fetal DNA in maternal plasma. Clin. Chem. 2008; 54:1664-72

8.Chan KC, Ding C, Gerovassili A, et al. Hypermethylated RASSF1A in maternal plasma: A universal fetal DNA marker that improves the reliability of noninvasive prenatal diagnosis. Clin Chem 2006; 52(12):2211-8.

9.Murtaza M, Dawson SJ, Tsui DW, et al. Non-invasive analysis of acquired resistance to cancer therapy by sequencing of plasma DNA. Nature. 2013; 497(7447):108-12.

10.Krebs MG, Metcalf RL, Carter L, et al. Molecular analysis of circulating tumour cellsbiology and biomarkers. Nat Rev Clin Oncol. 2014; 11(3):129-44.

11.Tsai NW, Lin TK, Chen SD, et al. The value of serial plasma nuclear and mitochondrial DNA levels in patients with acute ischemic stroke. Clin Chim Acta. 2011; 412(5-6):476-9.

12.Rodrigues Filho EM, Ikuta N, Simon D, et al. Prognostic value of circulating DNA levels in critically ill and trauma patients. Rev Bras Ter Intensiva. 2014; 26(3):305-12.

13.Lou X, Hou Y, Liang D, et al. A novel Alu-based real-time PCR method for the quantitative detection of plasma circulating cell-free DNA: sensitivity and specificity for the diagnosis of myocardial infarction. Int J Mol Med. 2015; 35(1):72-80.

14.Galeazzi M, Morozzi G, Piccini M, et al. Dosage and characterization of circulating DNA: present usage and possible applications in systemic autoimmune disorders. Autoimmun Rev. $2003 ; 2: 50-55$.

15.Zhong XY, Laivuori H, Livingston JC, et al. Elevation of both maternal and fetal extracellular circulating deoxyribonucleic acid concentrations in the plasma of pregnant women with preeclampsia. Am J Obstet Gynecol. 2001; 184:414-419. 
16.Guibert J, Benachi A, Grebille AG, et al. Kinetics of SRY gene appearance in maternal serum: detection by real time PCR in early pregnancy after assisted reproductive technique. Hum Reprod 2003; 18:1733-1736.

17. Wright CF, Wei Y, Higgins JPT, et al. Non-invasive prenatal diagnostic test accuracy for fetal sex using cell-free DNA a review and meta-analysis. BMC Res Notes. 2012; 5: 476.

18.Rouillac-Le Sciellour C, Puillandre P, Gillot R, et al. Large-scale pre-diagnosis study of fetal RHD genotyping by PCR on plasma DNA from RhD-negative pregnant women. Mol Diagn 2004; 8(1):23-31.

19.Chen EZ, Chiu RW, Sun H, et al. Noninvasive prenatal diagnosis of fetal trisomy 18 and trisomy 13 by maternal plasma DNA sequencing. PLoS One 2011; 6:e21791.

20.Ehrich M, Deciu C, Zwiefelhofer T, et al. Noninvasive detection of fetal trisomy 21 by sequencing of DNA in maternal blood: a study in a clinical setting. American journal of obstetrics and gynecology 2011; 204(3), 205-e1.

21.Palomaki GE, Kloza EM, Lambert-Messerlian GM, et al. DNA sequencing of maternal plasma to detect Down syndrome: an international clinical validation study. Genet Med 2011;13:913-20.011;204 [205 e201-211].

22.Bianchi DW, Platt LD, Goldberg JD, et al. Genomewide fetal aneuploidy detection by maternal plasma DNA sequencing. Obstet Gynecol 2012;119:890-901.

23. Norton ME, Brar H, Weiss J, et al. Non-Invasive Chromosomal Evaluation (NICE) Study: results of amulticenter prospective cohort study for detection of fetal trisomy 21 and trisomy 18. Am J Obstet Gynecol 2012; 207 [137 e131-138]. 
24.Gonzalez-Gonzalez MC, Trujillo MJ, de Alba MR, et al. Huntington diseaseunaffected fetus diagnosed from maternal plasma using QF-PCR. Prenat Diagn 2003; 23:232-4.

25.Bustamante-Aragones A, Trujillo-Tiebas MJ, Gallego-Merlo J, et al. Prenatal diagnosis of Huntington disease in maternal plasma: direct and indirect study. Eur J Neurol 2008; $15: 1338-44$.

26.Lun FM, Tsui NB, Chan KC, et al. Noninvasive prenatal diagnosis of monogenic diseases by digital size selection and relative mutation dosage on DNA in maternal plasma. Proc Natl Acad Sci USA 2008; 105:19920 - 5.

27.Barrett AN, McDonnell TC, Chan KC, et al. Digital PCR analysis of maternal plasma for noninvasive detection of sickle cell anemia. Clin Chem 2012; 58:1026 - 32.

28.Tsui NB, Kadir RA, Chan KC, et al. Noninvasive prenatal diagnosis of hemophilia by microfluidics digital PCR analysis of maternal plasma DNA. Blood 2011; 117:3684 - 91.

29.Lam KWG, Jiang P, Liao GJW, et al. Noninvasive prenatal diagnosis of monogenic diseases by targeted massively parallel sequencing of maternal plasma: application to betathalassemia. Clin Chem 2012; 58:1467-75.

30. Chitty LS, Mason S, Barrett AN, et al. Non-invasive prenatal diagnosis of achondroplasia and thanatophoric dysplasia: next generation sequencing allows for a safer, more accurate and comprehensive approach. Prenat Diagn. 2015. Accepted uneditable article published online.

31.Lo YM, Lun FM, Chan KC et al. Digital PCR for the molecular detection of fetal chromosomal aneuploidy. Proc Natl Acad Sci USA 2007; 104(32):13116-13121. 
32.Fan HC \& Quake SR. Detection of aneuploidy with digital polymerase chain reaction. Analytical chemistry. 2007; 79(19):7576-7579.

33.Evans MI, Wright DA, Pergament E, et al. Digital PCR for noninvasive detection of aneuploidy: power analysis equations for feasibility. Fetal diagnosis and therapy.2012; 31(4):244-247.

34. Saito H, Sekizawa A, Morimoto T, et al. Prenatal DNA diagnosis of a singlegene disorder from maternal plasma. Lancet 2000; 356:1170.

35.Li Y, Holzgreve W, Page-Christiaens GC, et al. Improved prenatal detection of a fetal point mutation for achondroplasia by the use of size-fractionated circulatory DNA in maternal plasma--case report. Prenat Diagn 2004;24:896-8.

36.Li Y, Page-Christiaens GC, Gille JJ, et al. Non-invasive prenatal detection of achondroplasia in size-fractionated cell free DNA by MALDI-TOF MS assay. Prenat Diagn 2007;27:11-17.

37.Lim JH, Kim MJ, Kim SY, et al. Non-invasive prenatal detection of achondroplasia using circulating fetal DNA in maternal plasma. J Assist Reprod Genet 2010; 28:167-72.

38.Chitty LS, Griffin DR, Meaney C, et al. New aids for the non-invasive prenatal diagnosis of achondroplasia: dysmorphic features, charts of fetal size and molecular confirmation using cell-free fetal DNA in maternal plasma. Ultrasound Obstet Gynecol 2011; 37:283-9.

39. Chitty LS, Khalil A, Barrett AN, et al. Safe, accurate, prenatal diagnosis of thanatophoric dysplasia using ultrasound and free fetal DNA. Prenat Diagn. 2013; 33(5): 416-423.

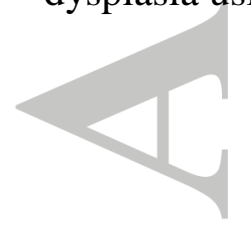




\begin{tabular}{|c|c|c|c|}
\hline & \multicolumn{2}{|c|}{ Oligonucleotidic Sequences of Primers and Probes } & Cycling Conditions \\
\hline $\begin{array}{l}\text { FGFR3 amplification before Sanger } \\
\text { Sequencing }\end{array}$ & $\begin{array}{l}\text { Forward Primer } \\
\text { Reverse Primer }\end{array}$ & $\begin{array}{l}\text { 5' GCG TGC TGA GGT TCT GAG 3' } \\
\text { 5' GAA TGT TTC GTG CCC CAA AG 3' }\end{array}$ & $\begin{array}{l}1 \text { cycle of } 95^{\circ} \mathrm{C} \text { for } 7 \mathrm{~min} / 40 \text { cycles of } 95^{\circ} \mathrm{C} \text { for } 30 \mathrm{sec}, 58^{\circ} \mathrm{C} \text { for } 30 \\
\mathrm{sec} \text {, and } 72^{\circ} \mathrm{C} \text { for } 30 \mathrm{sec} / 1 \mathrm{cycle} \text { of } 72^{\circ} \mathrm{C} \text { for } 7 \mathrm{~min}\end{array}$ \\
\hline $\begin{array}{l}\text { Sanger Sequencing Assay } \\
\text { FGFR3 }\end{array}$ & $\begin{array}{l}\text { Forward Primer } \\
\text { Reverse Primer }\end{array}$ & $\begin{array}{l}\text { 5' GCG TGC TGA GGT TCT GAG 3' } \\
\text { 5' GAA TGT TTC GTG CCC CAA AG 3' }\end{array}$ & $\begin{array}{l}1 \mathrm{cycle} \text { of } 96^{\circ} \mathrm{C} \text { for } 30 \mathrm{sec} / 30 \mathrm{cycles} \text { of } 96^{\circ} \mathrm{C} \text { for } 20 \mathrm{sec}, 50^{\circ} \mathrm{C} \text { for } 5 \\
\mathrm{sec} \text {, and } 60^{\circ} \mathrm{C} \text { for } 4 \mathrm{~min}\end{array}$ \\
\hline $\begin{array}{l}\text { ddPCR Assay } \\
\text { FGFR3_mutant A allele }\end{array}$ & $\begin{array}{l}\text { Forward Primer } \\
\text { Reverse Primer } \\
\text { Mutant A Probe } \\
\text { Wild-type G Probe }\end{array}$ & $\begin{array}{l}\text { 5' CAG TGT GTA TGC AGG C 3' } \\
\text { 5' ACC ACC AGG ATG AAC AG 3' } \\
\text { 5' AGC TAC aGG GTG GGC (Fam) (lowaBlack) 3' } \\
\text { 5' AGC TAC GGG GTG GGC (Hex) (lowaBlack) 3' }\end{array}$ & $\begin{array}{l}1 \text { cycle of } 95^{\circ} \mathrm{C} \text { for } 10 \mathrm{~min} / 40 \text { cycles of } 94^{\circ} \mathrm{C} \text { for } 30 \mathrm{sec} \text { and } 57^{\circ} \mathrm{C} \text { for } \\
\mathrm{min} / 1 \mathrm{cycle} \text { of } 98^{\circ} \mathrm{C} \text { for } 10 \mathrm{~min}\end{array}$ \\
\hline $\begin{array}{l}\text { ddPCR Assay } \\
\text { FGFR3_mutant Callele }\end{array}$ & $\begin{array}{l}\text { Forward Primer } \\
\text { Reverse Primer } \\
\text { Mutant C Probe } \\
\text { Wild-type G Probe }\end{array}$ & $\begin{array}{l}\text { 5' CAG TGT GTA TGC AGG C 3' } \\
\text { 5' ACC ACC AGG ATG AAC AG 3' } \\
\text { 5' CTA CCG GGT GGG CTT (Fam) (lowaBlack) 3' } \\
\text { 5' CTA CGG GGT GGG CTT (Hex) (lowaBlack) 3' }\end{array}$ & $\begin{array}{l}1 \text { cycle of } 95^{\circ} \mathrm{C} \text { for } 10 \mathrm{~min} / 40 \text { cycles of } 94^{\circ} \mathrm{C} \text { for } 30 \mathrm{sec} \text { and } 57^{\circ} \mathrm{C} \text { for } \\
\mathrm{min} / 1 \text { cycle of } 98^{\circ} \mathrm{C} \text { for } 10 \mathrm{~min}\end{array}$ \\
\hline $\begin{array}{l}\text { ddPCR Assay } \\
\text { RASSF1A* }\end{array}$ & $\begin{array}{l}\text { Forward Primer } \\
\text { Reverse Primer } \\
\text { Probe }\end{array}$ & $\begin{array}{l}\text { 5' AGC CTG AGC TCA TTG AGC TG 3' } \\
\text { 5' ACC AGC TGC CGT GTG G 3' } \\
\text { 5' (Fam) CCA ACG CGC TGC GCA T (MGB) 3' }\end{array}$ & $\begin{array}{l}1 \text { cycle of } 95^{\circ} \mathrm{C} \text { for } 10 \mathrm{~min} / 40 \text { cycles of } 94^{\circ} \mathrm{C} \text { for } 30 \mathrm{sec} \text { and } 57^{\circ} \mathrm{C} \text { for } \\
\mathrm{min} / 1 \mathrm{cycle} \text { of } 98^{\circ} \mathrm{C} \text { for } 10 \mathrm{~min}\end{array}$ \\
\hline $\begin{array}{l}\text { ddPCR Assay } \\
\text { ACTIN } B^{*}\end{array}$ & $\begin{array}{l}\text { Forward Primer } \\
\text { Reverse Primer } \\
\text { Probe }\end{array}$ & $\begin{array}{l}\text { 5' GCG CCG TTC CGA AAG TT 3' } \\
\text { 5' CGG CGG ATC GGC AAA 3' } \\
\text { 5' (ViC) ACC GCC GAG ACC GCG TC (MGB) 3' }\end{array}$ & $\begin{array}{l}1 \text { cycle of } 95^{\circ} \mathrm{C} \text { for } 10 \mathrm{~min} / 40 \text { cycles of } 94^{\circ} \mathrm{C} \text { for } 30 \mathrm{sec} \text { and } 57^{\circ} \mathrm{C} \text { for } \\
\mathrm{min} / 1 \mathrm{cycle} \text { of } 98^{\circ} \mathrm{C} \text { for } 10 \mathrm{~min}\end{array}$ \\
\hline $\begin{array}{l}\text { FGFR3 amplification before } \\
\text { Minisequencing Assay }\end{array}$ & $\begin{array}{l}\text { Forward Primer } \\
\text { Reverse Primer }\end{array}$ & $\begin{array}{l}\text { 5' CAG GCC TCA ACG CCC ATG TC 3' } \\
\text { 5' GGG GAG CCC AGG CCT TTC Tा 3' }\end{array}$ & $\begin{array}{l}1 \mathrm{cycle} \text { of } 95^{\circ} \mathrm{C} \text { for } 10 \mathrm{~min} / 55 \mathrm{cycles} \text { of } 95^{\circ} \mathrm{C} \text { for } 10 \mathrm{sec}, 68^{\circ} \mathrm{C} \text { for } 10 \\
\text { sec and } 72^{\circ} \mathrm{C} \text { for } 15 \mathrm{sec} / 1 \mathrm{cycle} \text { of } 72^{\circ} \mathrm{C} \text { for } 7 \mathrm{~min}\end{array}$ \\
\hline $\begin{array}{l}\text { Minisequencing Assay } \\
\text { FGFR3 }\end{array}$ & Forward Primer & $\begin{array}{l}\text { 5' aaaaaaaaaaaaaaaaaaaaaaaaaaaaaa ATG CAG GCA } \\
\text { TCC TCA GCT AC 3' } \\
\text { 5' tttttttttttttttttttttttttt GAA CAG GAA GAA GCC CAC } \\
\text { CC } 3^{\prime}\end{array}$ & $\begin{array}{l}1 \mathrm{cycle} \text { of } 96^{\circ} \mathrm{C} \text { for } 10 \mathrm{sec} / 25 \mathrm{cycles} \text { of } 96^{\circ} \mathrm{C} \text { for } 10 \mathrm{sec}, 50^{\circ} \mathrm{C} \text { for } 5 \mathrm{sec} \\
\text { and } 60^{\circ} \mathrm{C} \text { for } 30 \mathrm{sec}\end{array}$ \\
\hline
\end{tabular}

Table 1. Oligonucleotidic sequences of primers and probes, and cycling conditions used in the different assays.

* described by Chan et al, 2006 


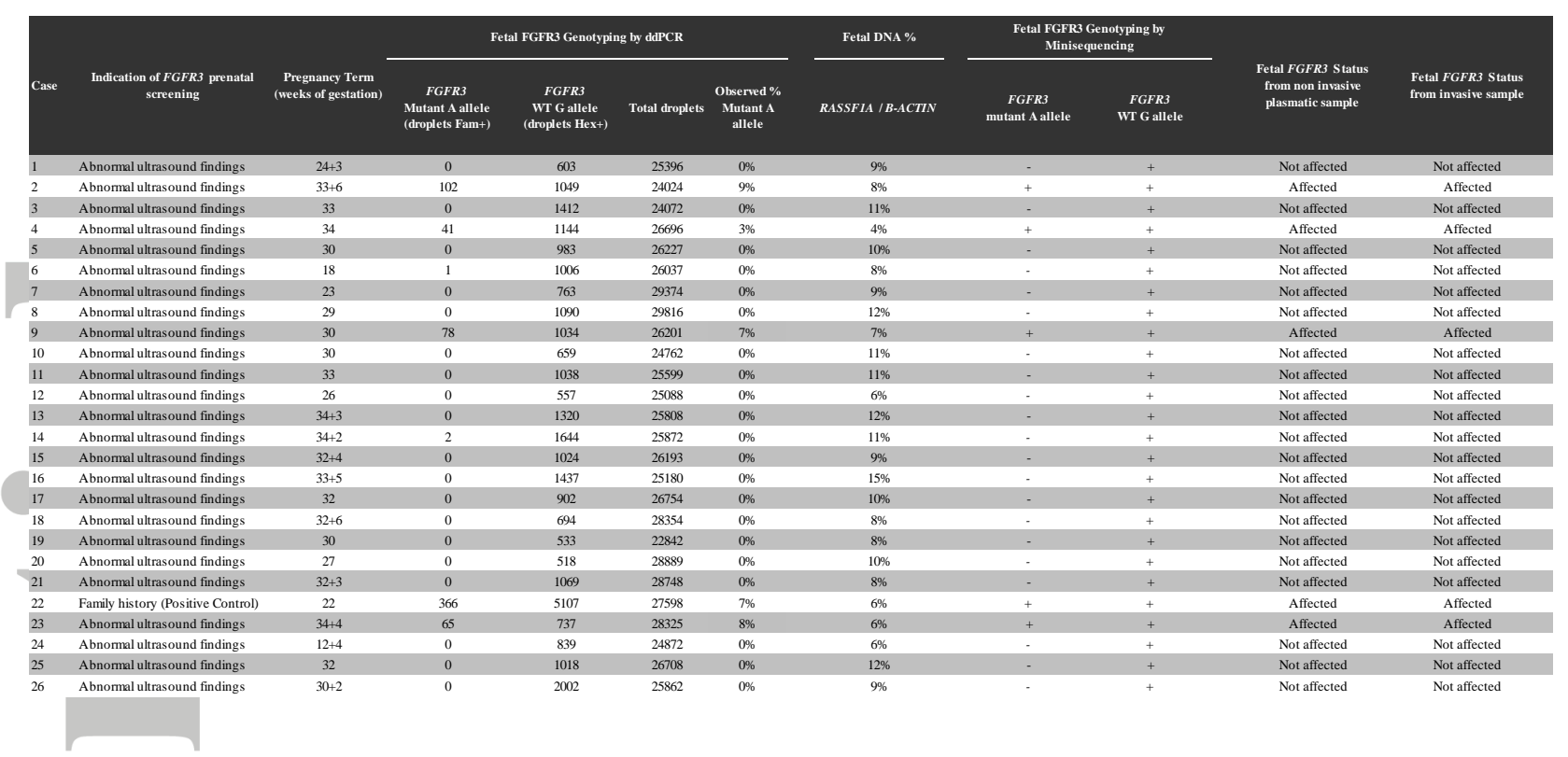

Table 2. FGFR3 fetal genotype classification. Indication for prenatal screening, pregnancy term, results of noninvasive testing from plasmatic samples, ddPCR and minisequencing assays, and results testing from invasive sample are presented. WT $=$ Wild-type.

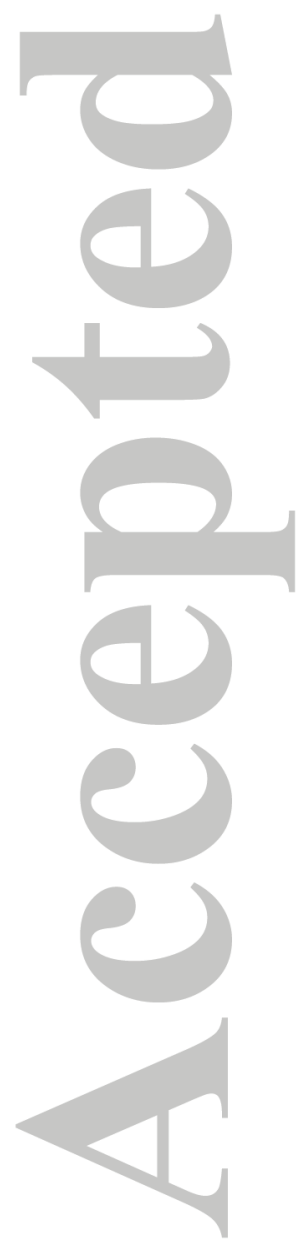


Maternal blood sample on BCT collection tube
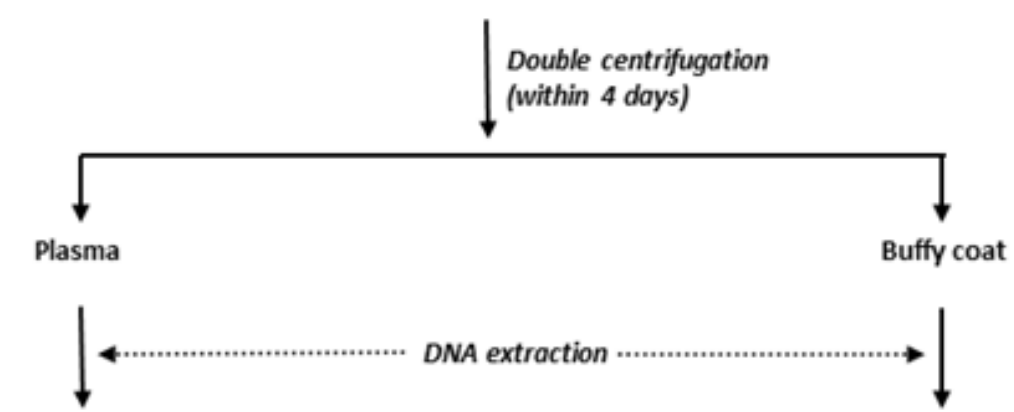

Plasmatic DNA

(maternal + fetal)

Nuclear DNA

(maternal)

ddPCR duplex

FGFR3 mutant_G>A assay

FGFR3 mutant_G>C assay

FGFR3 mutant $\mathrm{A}$ allele $(+)$ FGFR3_mutant_C allele (-) FGFR3_WT_G allele (+)

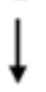

Presence of FGFR3 mutant A allele in the blood sample of a non affected mother

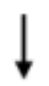

Achondroplastic fetus with FGFR3 c.1138G>A mutation

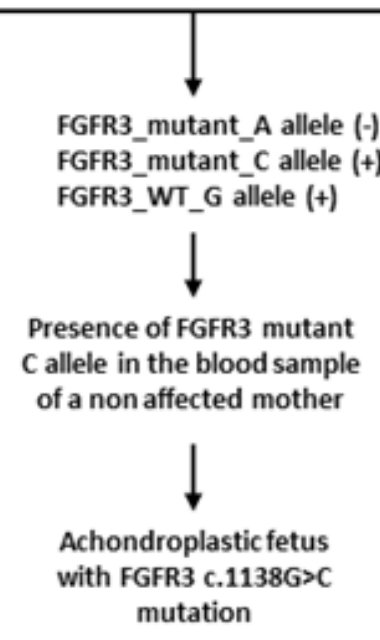

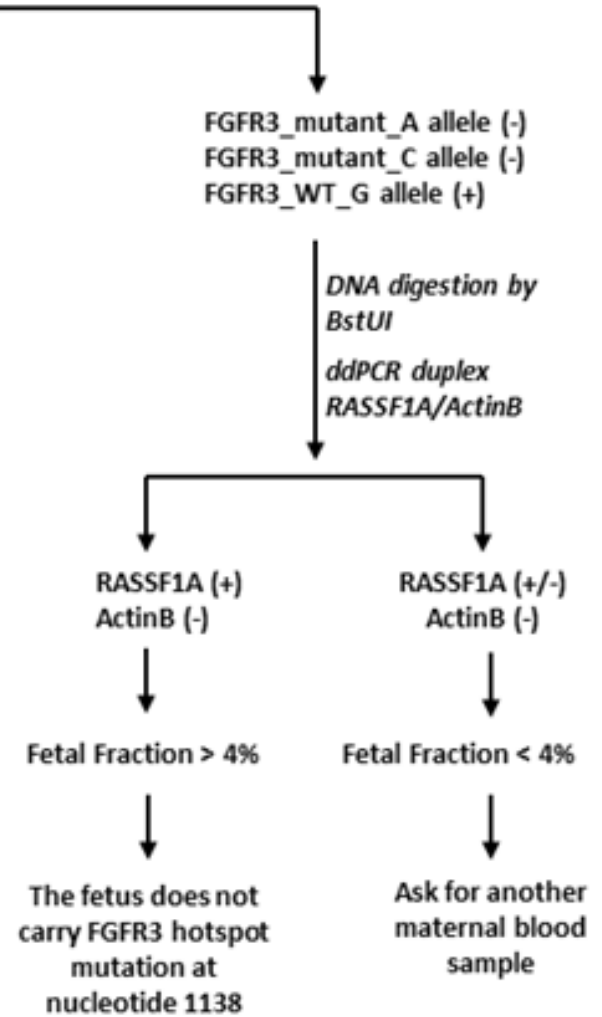

Figure 1. Decision algorithm for ddPCR assay.

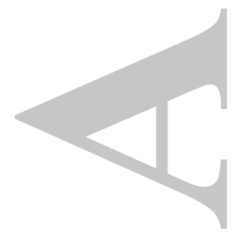



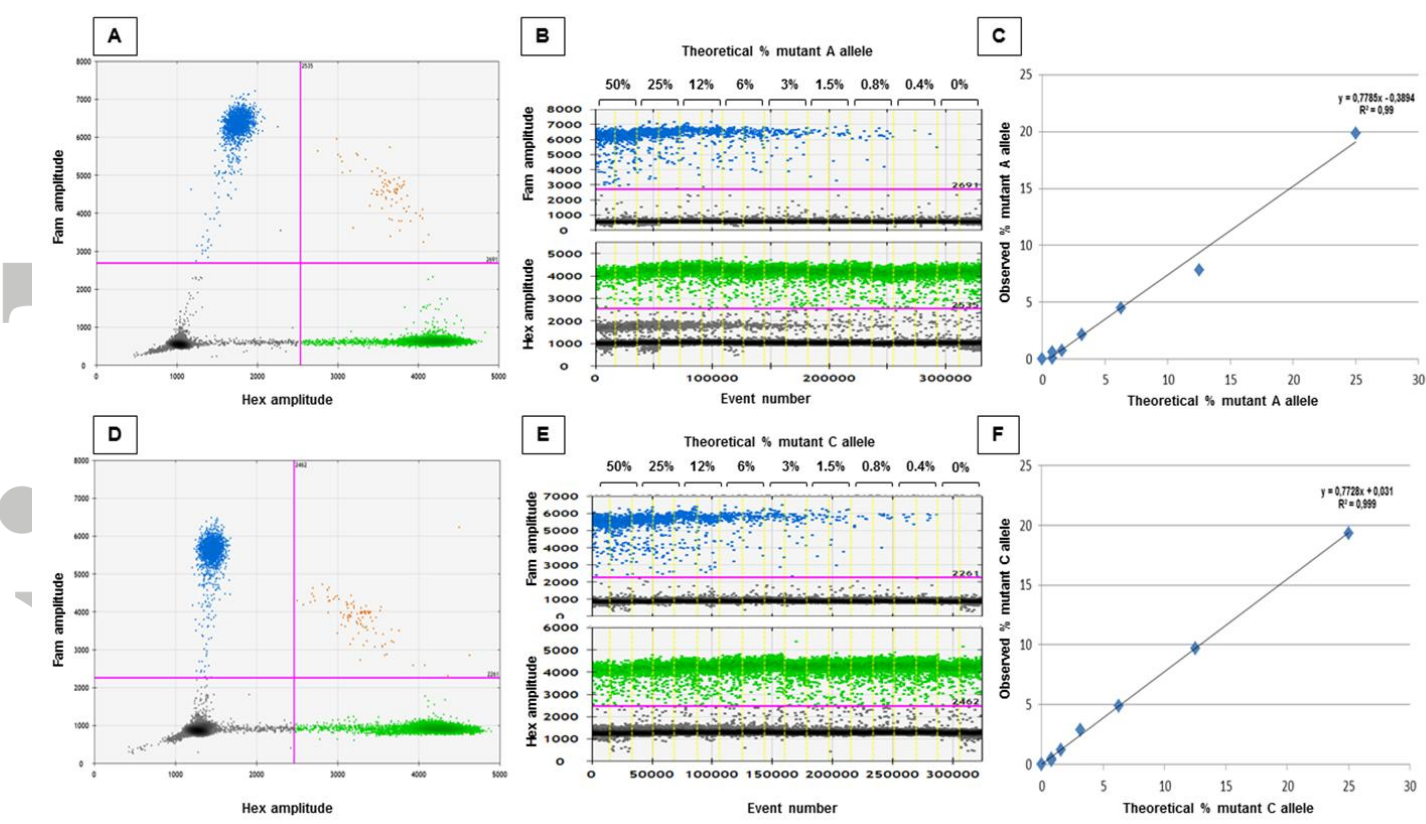

Figure 2. Validation of the ddPCR assays - serial dilutions for each set of probes with artificial mixtures of $0.5 \mathrm{ng} / \mu \mathrm{L}$ DNA from peripheral blood leucocytes with a mutant content of $50 \%, 25 \%, 12 \%, 6 \%, 3 \%, 1.5 \%, 0.8 \%, 0.4 \%$ or $0 \%$. A and D. Two-dimensional representation of the fluorescence intensity obtained by ddPCR using FGFR3 mutant A (A) and FGFR3 mutant $\mathrm{C}$ (D) ddPCR assays, respectively. The $\mathrm{y}$ and $\mathrm{x}$ axes correspond to the FAM and HEX intensities, for mutant and WT alleles respectively. Negative droplets (grey dots) and positive ones (blue dots for FAM+ only, green dots for HEX+ only and brown for FAM+ and $\mathrm{HEX}+$ ) are assigned as a function of the FAM and HEX florescence amplitudes. B and E. One dimensional representation of the fluorescence intensity obtained by ddPCR using FGFR3 mutant A (B) and FGFR3 mutant C (E) ddPCR assays, respectively. Each column corresponds to one point of the serial dilution mixture of $0.5 \mathrm{ng} / \mu \mathrm{L}$ DNA with a mutant content of $50 \%, 25 \%, 12 \%, 6 \%, 3 \%, 1.5 \%, 0.8 \%, 0.4 \%$ or $0 \%$. C and F. Correlation between observed vs. theoretical ratios using FGFR3 mutant $\mathrm{A}(\mathbf{C})$ and $F G F R 3$ mutant $\mathrm{C}(\mathbf{F})$ ddPCR assays, respectively. Each point corresponds to one point of the serial dilution mixture of $0.5 \mathrm{ng} / \mu \mathrm{L}$ DNA with a mutant content of $50 \%, 25 \%, 12 \%, 6 \%, 3 \%, 1.5 \%, 0.8 \%$, $0.4 \%$ or $0 \%$. 

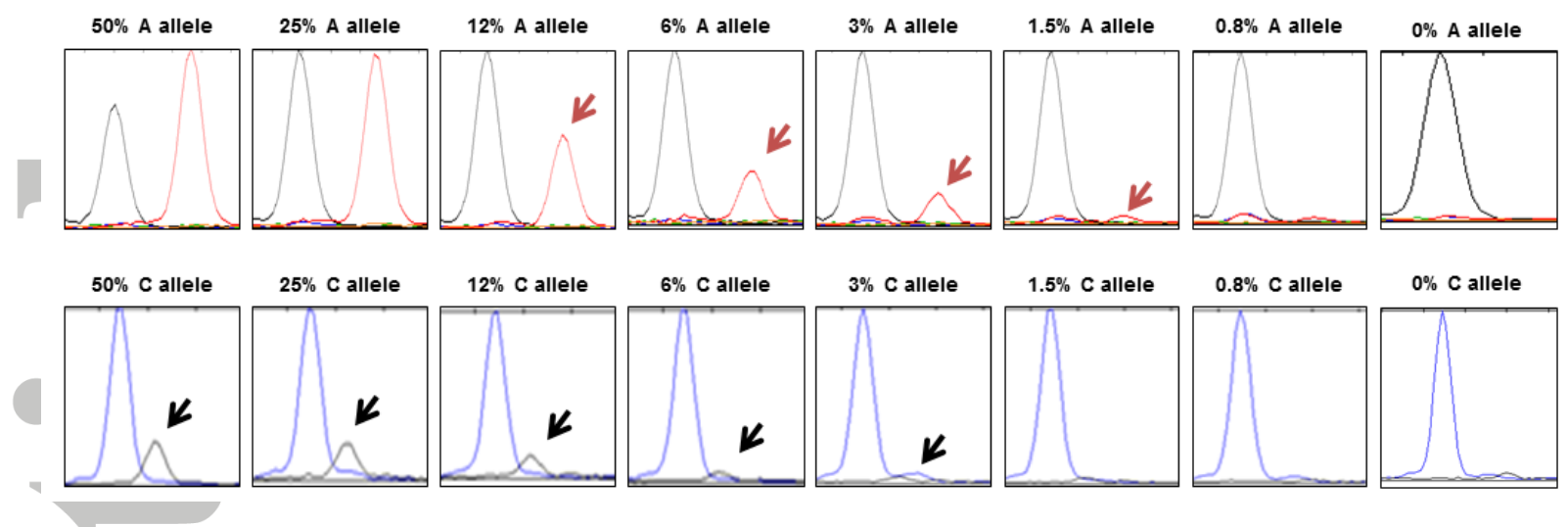

Figure 3. Validation of the minisequencing assays - serial dilutions for each set of probes with artificial mixtures of $0.5 \mathrm{ng} / \mu \mathrm{L}$ DNA from peripheral blood leucocytes with mutant-A allele (up) or mutant-C allele (down) content of 50\%, 25\%, 12\%, 6\%, 3\%, 1.5\%, $0.8 \%$ or $0 \%$.

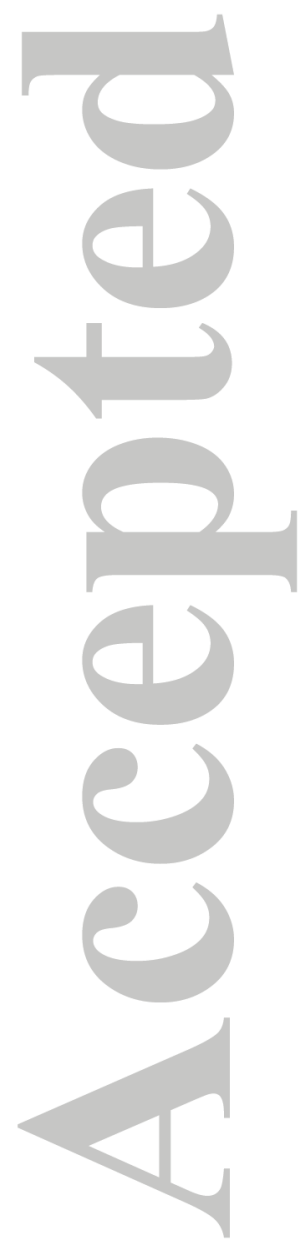



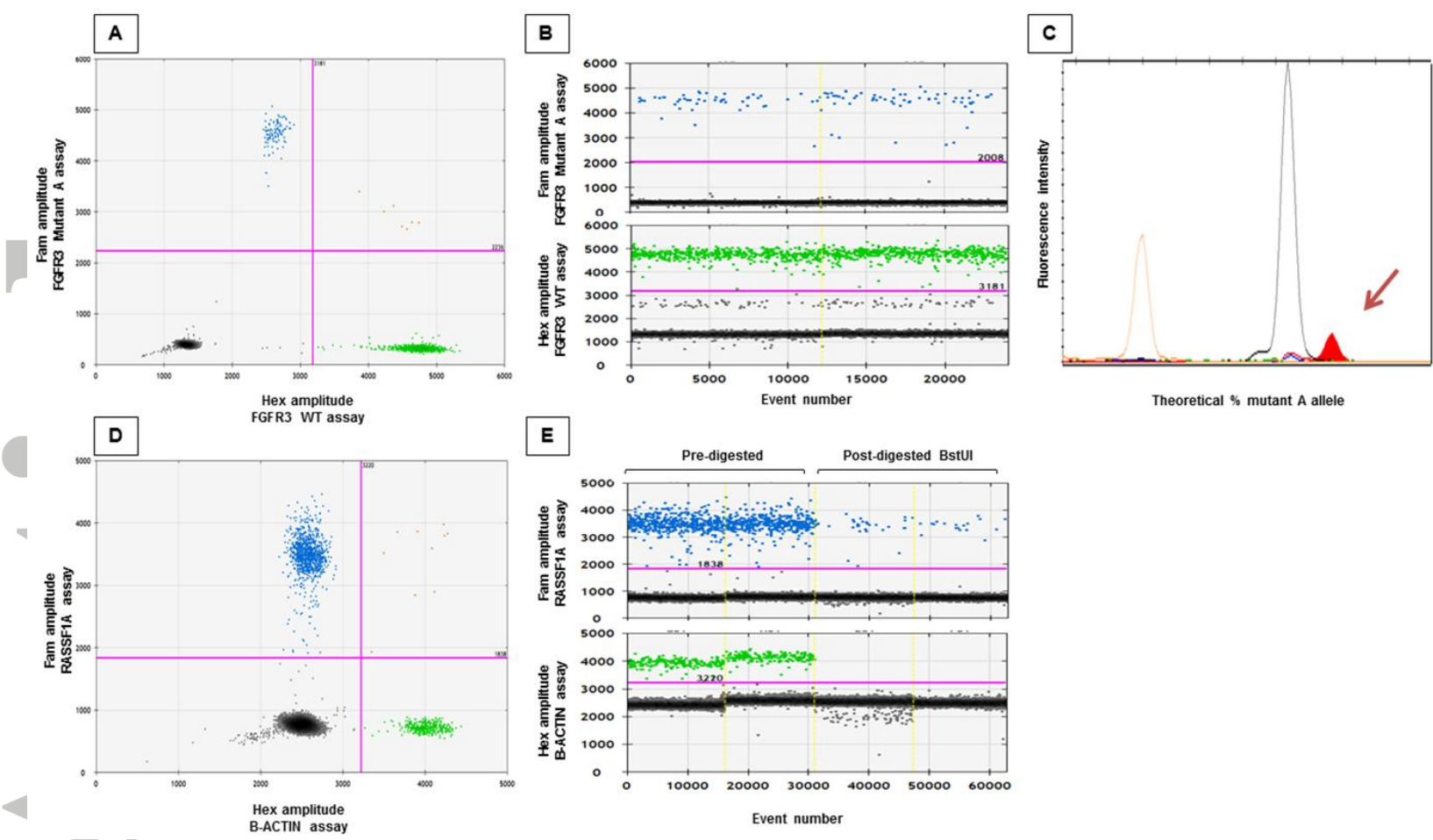

Figure 4. Genotyping the $F G F R 3$ c. $1138 \mathrm{G}>\mathrm{A}$ mutation by ddPCR and minisequencing assays in plasmatic DNA from maternal blood at 22 weeks of pregnancy. A and D. Twodimensional representation of the fluorescence intensity obtained by ddPCR using FGFR3 mutant A-allele ddPCR assay (A) and RASSF1A/ B-ACTIN assay (D), respectively. B and E. One dimensional representation of the fluorescence intensity obtained by ddPCR using FGFR3 mutant A-allele ddPCR assay (B) and RASSF1A/ B-ACTIN assay before and after BstUI digestion (E), respectively. C. Minisequencing electrophoregram. The brown pic corresponds to the size marker, the black pic corresponds to the WT G-allele, and the red pic corresponds to the mutant A-allele. 